Supporting information

\title{
Best Practice: Performance and Cost Evaluation of Lithium Ion Battery Active Materials with Special Emphasis on Energy Efficiency
}

\author{
Paul Meister, Haiping Jia, Jie Li, Richard Kloepsch, Martin Winter, Tobias Placke
}

\section{Experimental details for the preparation of the electrodes:}

Electrode tapes for the negative electrode were prepared by dissolving the appropriate amount (either $5 \mathrm{wt} . \%$ for carbons or $10 \mathrm{wt} . \%$ for $\mathrm{Si} / \mathrm{C}$ and $\mathrm{ZFO}$ ) of sodiumcarboxymethylcellulose (Na-CMC) in de-ionized water. A certain amount of carbon black Super C65 (either 5 wt.\% for carbons or $10 \mathrm{wt} . \%$ for $\mathrm{Si} / \mathrm{C}$ and $\mathrm{ZnFe}_{2} \mathrm{O}_{4}$ ) was admixed to the binder solution and further equilibrated. Thereafter, the active material was introduced into the paste and the whole mixture was further stirred. Subsequently, a high-energy dispersion step (T 25 Ultra Turrax, 1 h, $5000 \mathrm{rpm}$ ) was conducted to eliminate agglomerates and to homogenize the mixture. The paste was cast on dendritic copper foil by means of a standard lab-scale doctorblade technique. After the coating process, the tapes were transferred into an oven and dried at $80{ }^{\circ} \mathrm{C}$ for one hour.

The preparation of the electrode tapes for the positive electrode was executed in a similar way. In the first step, the appropriate amount of the binder polyvinylidene difluoride (PVdF) was dissolved in $N$-Methyl-2-pyrrolidone (NMP), followed by the addition of the conductive additive Super C65 (Imerys). After equilibration of the mixture, the active material was added and the whole paste was further homogenized by ball milling. The resulting slurry was cast with a doctor-blade technique on aluminum foil. In the next step, the electrode were dried at $80{ }^{\circ} \mathrm{C}$ in an atmospheric oven.

Electrode discs with a diameter of $12 \mathrm{~mm}$ were cut from the electrode sheets of the anode and cathode and further dried under reduced pressure $(<0.05 \mathrm{mbar})$ at $120^{\circ} \mathrm{C}$ over night. In the last step, the electrodes were transferred into an argon-filled glove box (UniLab, MBraun) with oxygen and water contents of less than $1 \mathrm{ppm}$. 
Table S1: Overview of the electrode composition for graphite, soft carbon, silicon/graphite, ZFO, $\mathrm{LiNi}_{0.5} \mathrm{Mn}_{1.5} \mathrm{O}_{4}(\mathrm{LNMO}), \quad 0.5 \mathrm{Li}_{2} \mathrm{MnO}_{3} \cdot 0.5 \quad \mathrm{LiNi}_{0.4} \mathrm{Mn}_{0.4} \mathrm{Co}_{0.2} \mathrm{O}_{2}$ (LR-NMC) and $\mathrm{LiNi}_{1 / 3} \mathrm{Mn}_{1 / 3} \mathrm{Co}_{1 / 3} \mathrm{O}_{2}(\mathrm{NMC}-111)$ electrodes.

\begin{tabular}{ccccc}
\hline $\begin{array}{c}\text { Composite electrode } \\
\text { active material }\end{array}$ & Active material (\%) & $\begin{array}{c}\text { Conductive additive } \\
\text { Carbon black } \\
\text { Super C65(\%) }\end{array}$ & $\begin{array}{c}\text { Binder } \\
\text { Na-CMC }\end{array}$ & $\begin{array}{c}\text { PVdF } \\
(\%)\end{array}$ \\
\hline Graphite & 90 & 5 & 5 & - \\
Soft Carbon & 90 & 5 & 5 & - \\
Silicon/graphite & $20 / 60$ & 10 & 10 & - \\
ZFO & 80 & 10 & 10 & - \\
LNMO & 80 & 10 & - & 10 \\
LR-NMC & 80 & 10 & - & 10 \\
NMC-111 & 85 & 8 & - & 7 \\
\hline
\end{tabular}

Table S2: Overview of the average mass loadings for graphite, soft carbon, silicon/graphite, ZFO, $\mathrm{LiNi}_{0.5} \mathrm{Mn}_{1.5} \mathrm{O}_{4}$ (LNMO), $0.5 \mathrm{Li}_{2} \mathrm{MnO}_{3} \cdot 0.5 \quad \mathrm{LiNi}_{0.4} \mathrm{Mn}_{0.4} \mathrm{Co}_{0.2} \mathrm{O}_{2}$ (LR-NMC) and $\mathrm{LiNi}_{1 / 3} \mathrm{Mn}_{1 / 3} \mathrm{Co}_{1 / 3} \mathrm{O}_{2}(\mathrm{NMC}-111)$ composite electrodes.

\begin{tabular}{cc}
\hline Composite electrode active material & Mass loading $\left(\mathbf{m g ~ c m}^{-\mathbf{2}}\right)$ \\
\hline Graphite & $3.6 \pm 0.1$ \\
Soft Carbon & $3.9 \pm 0.1$ \\
Silicon/graphite & $2.0 \pm 0.1$ \\
ZFO & $0.9 \pm 0.1$ \\
LNMO & $3.1 \pm 0.1$ \\
LR-NMC & $2.2 \pm 0.1$ \\
NMC-111 & $3.2 \pm 0.1$ \\
\hline
\end{tabular}

\section{Calculation of the specific energy of full cells with different anode/cathode ratios:}

For the calculation of the specific energy on the full cell level, three different anode materials, namely graphite, silicon/graphite composite and ZFO have been selected in combination with a $\mathrm{LiFePO}_{4}$ cathode. The calculations can be found below. Since the calculation should rather present a trend than absolute values, a simple approach was applied. We assumed for this model a practical capacity of $3.09 \mathrm{mAh} \mathrm{cm}^{-2}$ for the LFP cathode which is in accordance with the value published by Berg et al. ${ }^{1}$ Depending on the anode/cathode balancing ratio, the anode exhibited an oversized practical capacity of $0 \%, 10 \%$ or $20 \%$. Depending on the $1^{\text {st }}$ cycle Coulombic efficiency of the respective anode material, a different 
theoretical capacity $\left(\mathrm{mAh} \mathrm{cm}^{-2}\right)$ results. By the theoretical specific capacity $\left(\mathrm{mAh} \mathrm{g}^{-1}\right)$ and the theoretical capacity $\left(\mathrm{mAh} \mathrm{cm}^{-2}\right)$, it is possible to calculate the active material mass loading of the materials.

Generally, the specific energy of a cell can be determined by following equation:

$$
\text { Specific energy }\left(\frac{W h}{k g}\right)=\frac{\text { cell voltage }(\mathrm{V}) \cdot \operatorname{cell} \text { capacity }(\mathrm{Ah})}{\text { total weight }(\mathrm{kg})}
$$

The cell voltage was obtained as the difference of the practical average discharge potential of LFP and the respective anode materials. The cell capacity was limited by the cathode capacity of $3.09 \mathrm{mAh} \mathrm{cm}^{-2}$. The specific energy on the cell level was calculated as product of the cell voltage and the cell capacity, divided by the active material mass loading of anode and cathode. For simplicity reasons the total cell capacity is calculated without taking into account the inactive cell components. Thus, the specific energy values presented in our calculations are only based on the active material weights of anode and cathode materials.

In consideration of the above stated assumptions and simplifications, the specific energy of the different full cell configurations are illustrated in Table 2. To estimate the influence of the $1^{\text {st }}$ cycle CE on the energy, a second calculation with an analogous calculation was made. However, the values presented in Table 3 take into account the benefit of a pre-lithiation step, which is assumed to result in a first cycle Coulombic efficiency of $100 \%$. One has to note that our reported values are relatively high owing to the fact that the weight of the inactive materials is not included in the calculations.

\section{Determination of the Energy Efficiency of different LIB materials:}

Generally, the energy efficiency was determined by the ratio of the discharge energy to the charge energy. For the determination of the EE of anode materials, an imaginary LFP cathode providing a constant potential of $3.4 \mathrm{~V}$ vs. $\mathrm{Li} / \mathrm{Li}^{+}$was used (Figure S1a). Hence, the area between the cathode potential and the discharge/charge curve is used to calculate the discharge or charge energy. The energy efficiency of the cathode materials was obtained in a similar way. However, the upper limit is given by the discharge/charge curves of the cathode material, while the lower limit is set as $0 \mathrm{~V}$ vs. $\mathrm{Li} / \mathrm{Li}^{+}$(Figure $\mathrm{S} 1 \mathrm{~b}$ ). By integration of the above mentioned areas, the changes of the cell voltage and the capacity with varying state of charge is considered. The reported absolute EE values would be different if other parameters such as another cathode potential as upper limit in Figure S1a are applied. 


\section{Figure S1}
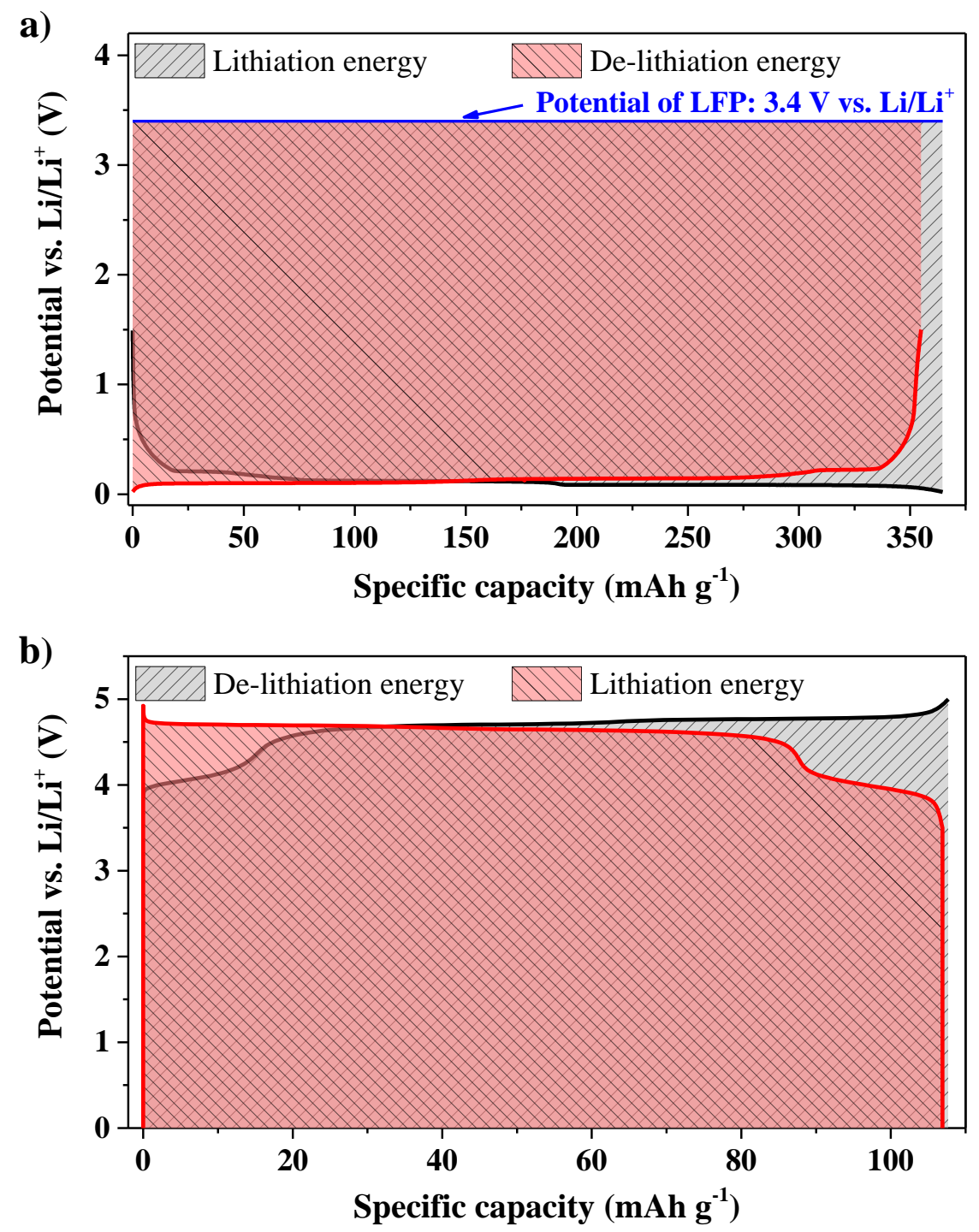

Figure S1. Schematic illustration of the determination of the energy efficiency by means of potential vs. specific capacity profiles of a) anode (= graphite) and b) cathode (= LNMO) materials. 
Figure S2

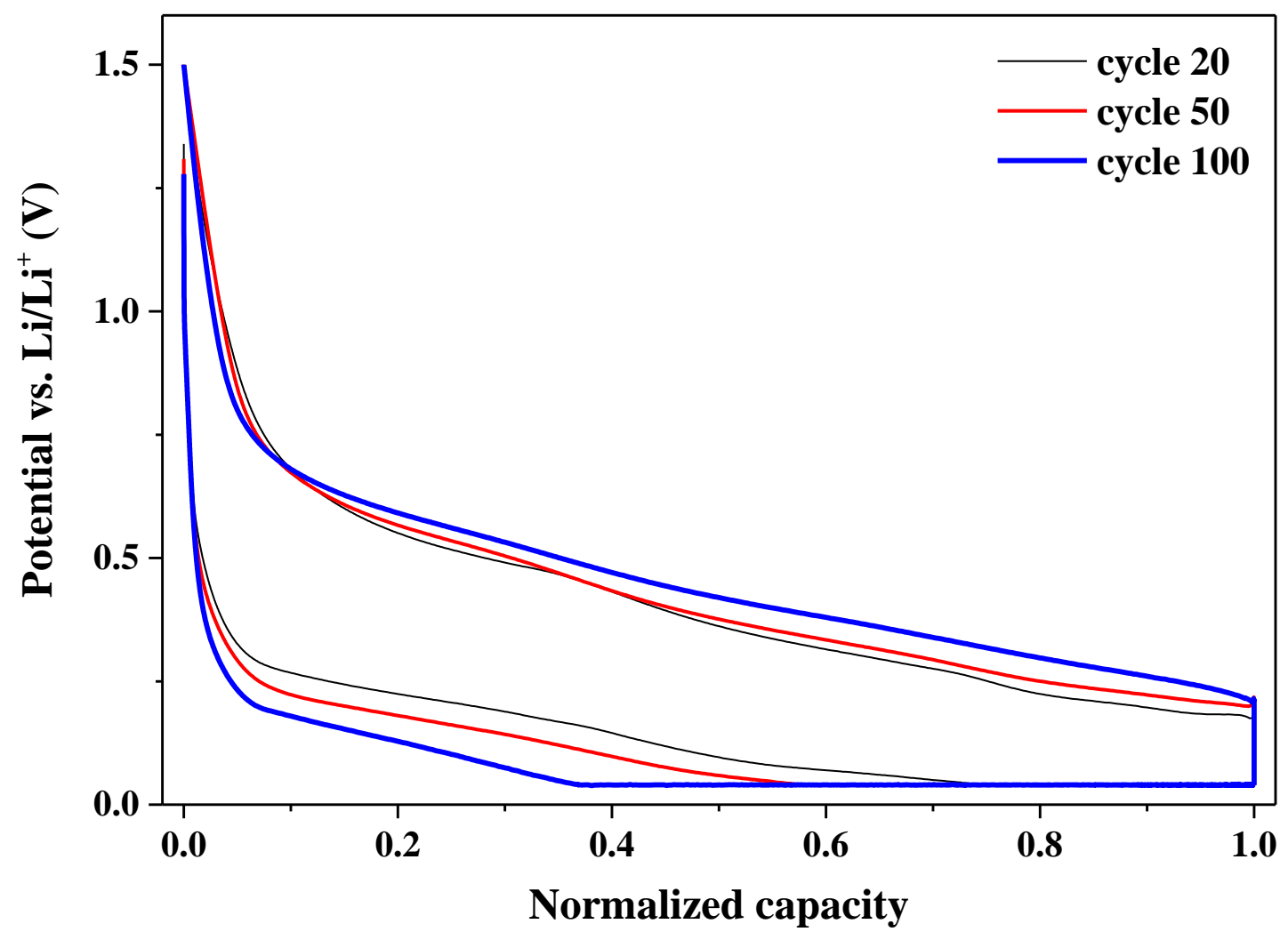

Figure S2. Comparison of the potential vs. normalized capacity plots of silicon/graphite (Si/C) composite electrodes in cycle 20,50 and 100. 
Figure S3
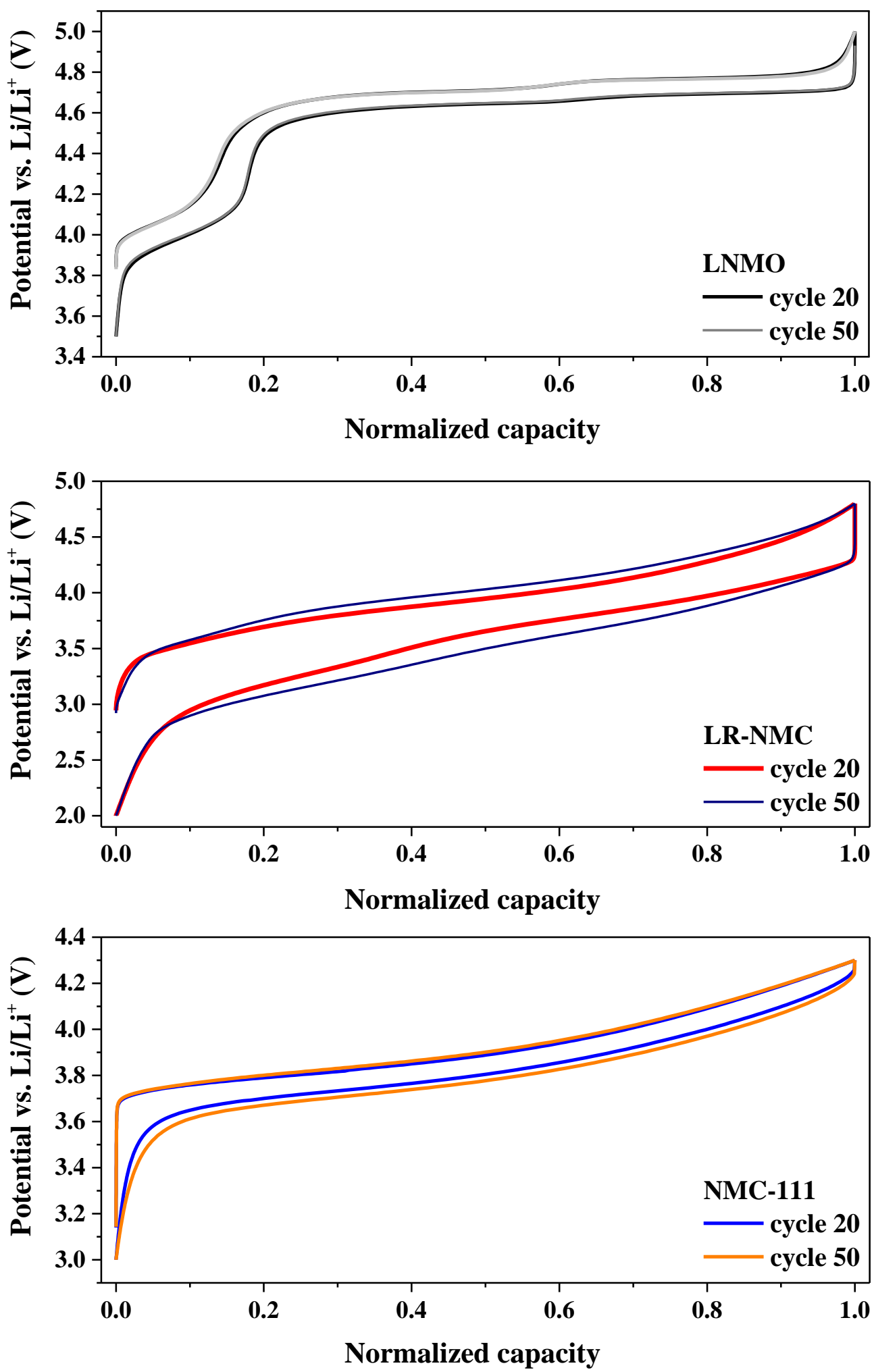

Figure S3. Comparison of the potential vs. normalized capacity plots of $\mathrm{LiNi}_{0.5} \mathrm{Mn}_{1.5} \mathrm{O}_{4}$ (LNMO), $0.5 \mathrm{Li}_{2} \mathrm{MnO}_{3} \cdot 0.5 \mathrm{LiNi}_{0.4} \mathrm{Mn}_{0.4} \mathrm{Co}_{0.2} \mathrm{O}_{2}$ (LR-NMC) and $\mathrm{LiNi}_{1 / 3} \mathrm{Mn}_{1 / 3} \mathrm{Co}_{1 / 3} \mathrm{O}_{2}$ (NMC-111) electrodes in cycle 20 and 50. 


\section{Figure S4}

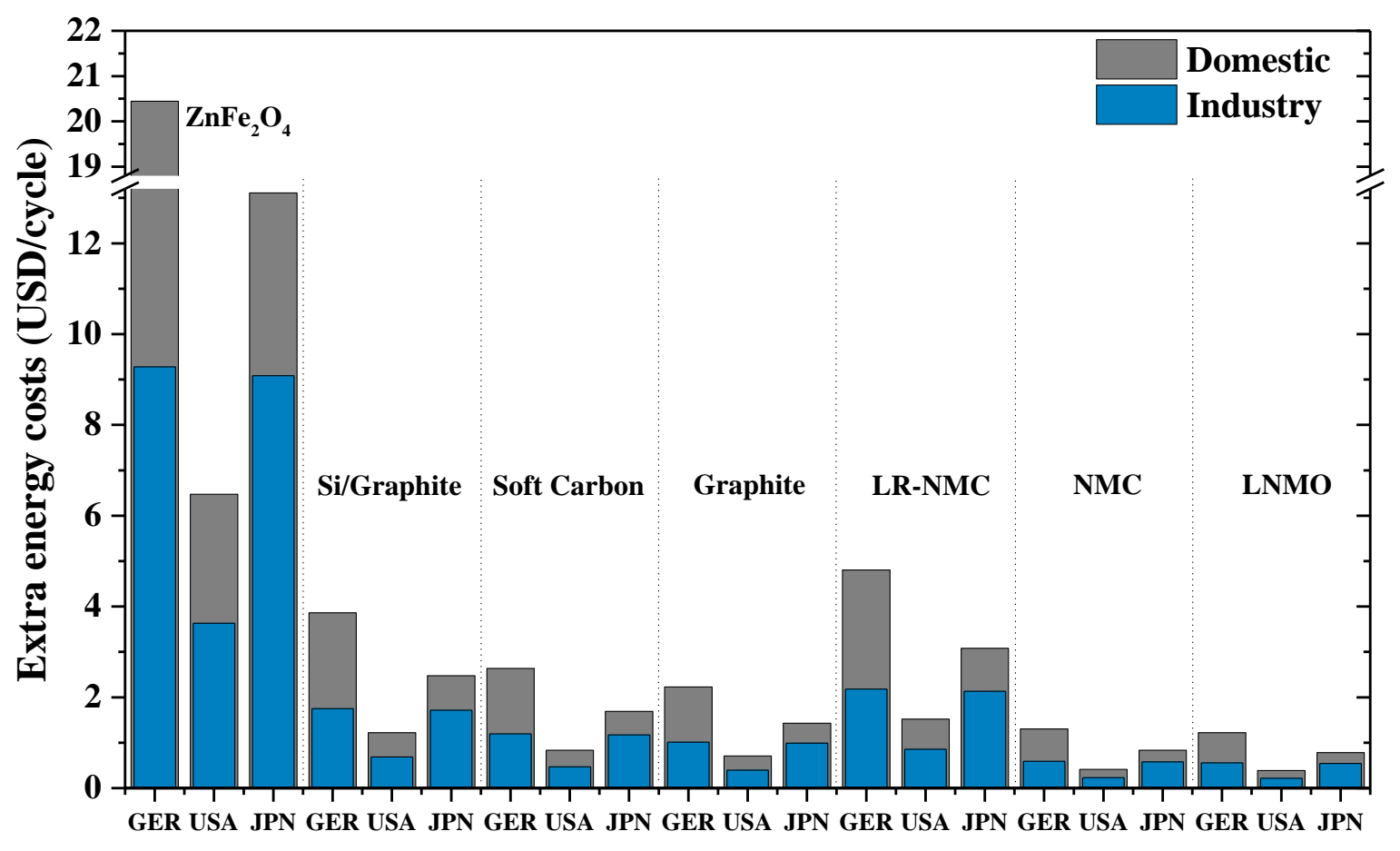

Figure S4. Overview of the extra energy costs per cycle in Germany, Japan and in the USA of ZFO, silicon/graphite composite, soft carbon, and graphite anodes as well as LR-NMC, NMC-111 and LNMO cathodes that are needed to compensate the energy inefficiency of the different materials in order to maintain an energy of $90 \mathrm{kWh}$ during discharge. The cost calculation is based on the annual data for the electricity prices in 2014 including taxes of the respective country.

\section{References}

1. Berg, E. J.; Villevieille, C.; Streich, D.; Trabesinger, S.; Novák, P., Rechargeable Batteries: Grasping for the Limits of Chemistry. Journal of the Electrochemical Society 2015, 162, (14), A2468A2475. 
Assumptions

The practical capacity of $3.09 \mathrm{mAh} / \mathrm{cm}^{2}$ is based on the data presented by Berg et al.

(E. J. Berg, C. Villevieille, D. Streich, S. Trabesinger and P. Novák, J Electrochem Soc, 2015, 162, A2468-A2475.)

without pre-lithiation

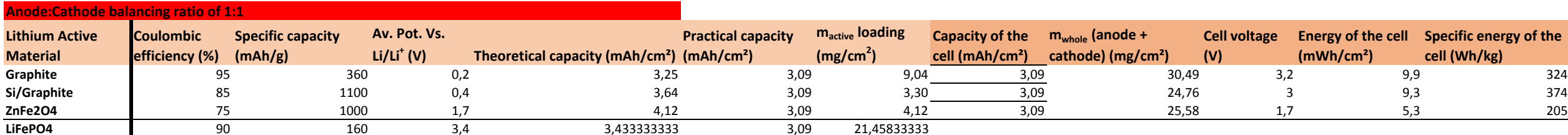

160

3,433333333

$3,09-21,45833333$

Practical capacity $m_{\text {active }}$ loading Capacity of the $m_{\text {whole }}$ (anode + Cell voltage Energy of the cell Specific energy of the

\begin{tabular}{|c|c|c|c|c|c|c|c|c|c|c|c|}
\hline $\begin{array}{l}\text { Lithium Active } \\
\text { Material }\end{array}$ & $\begin{array}{l}\text { Coulombic } \\
\text { efficiency (\%) }\end{array}$ & $\begin{array}{l}\text { Specific capacity } \\
\text { (mAh/g) }\end{array}$ & $\begin{array}{l}\text { Av. Pot. Vs. } \\
\mathrm{Li}^{-\mathrm{Li}^{+}}(\mathrm{V})\end{array}$ & Theoretical capacity $\left(\mathrm{mAh} / \mathrm{cm}^{2}\right)$ & $\begin{array}{l}\text { Practical capacity } \\
\left(\mathrm{mAh} / \mathrm{cm}^{2}\right)\end{array}$ & $\begin{array}{l}\mathrm{m}_{\text {active loading }} \\
\left(\mathrm{mg} / \mathrm{cm}^{2}\right)\end{array}$ & $\begin{array}{l}\text { Capacity of the } \\
\text { cell }\left(\mathrm{mAh} / \mathrm{cm}^{2}\right)\end{array}$ & $\begin{array}{l}m_{\text {whole }}(\text { anode }+ \\
\text { cathode) }\left(\mathrm{mg} / \mathrm{cm}^{2}\right)\end{array}$ & $\begin{array}{l}\text { Cell voltage } \\
\text { (V) }\end{array}$ & $\begin{array}{l}\text { Energy of the cell } \\
\left(\mathrm{mWh} / \mathrm{cm}^{2}\right)\end{array}$ & $\begin{array}{l}\text { Specific energy of the } \\
\text { cell (Wh/kg) }\end{array}$ \\
\hline raphite & 95 & 360 & & 3,58 & 3,40 & 9,94 & 3,09 & 31,40 & 3,2 & 9,0 & 315 \\
\hline i/Graphite & 85 & 1100 & 0 & 4,00 & 3,40 & 3,64 & 3,09 & 25,09 & 3 & 9,3 & 369 \\
\hline $\mathrm{ZnFe2O4}$ & 75 & 1000 & 1, & 4,5 & 3,40 & 4,53 & 3,09 & 25,99 & 1,7 & 5,3 & 202 \\
\hline
\end{tabular}

\begin{tabular}{|c|c|c|c|c|c|c|c|c|c|c|c|}
\hline \multicolumn{12}{|c|}{ Anode:Cathode balancing ratio of 1.2:1 } \\
\hline $\begin{array}{l}\text { Lithium Active } \\
\text { Material }\end{array}$ & $\begin{array}{l}\text { Coulombic } \\
\text { efficiency (\%) }\end{array}$ & $\begin{array}{l}\text { Specific capacity } \\
\text { (mAh/g) }\end{array}$ & $\begin{array}{l}\text { Av. Pot. Vs. } \\
\mathrm{Li}^{\prime} \mathrm{Li}^{+}(\mathrm{V})\end{array}$ & Theoretical capacity $\left(\mathrm{mAh} / \mathrm{cm}^{2}\right)$ & $\begin{array}{l}\text { Practical capacity } \\
\left(\mathrm{mAh} / \mathrm{cm}^{2}\right)\end{array}$ & $\begin{array}{l}m_{\text {active loading }} \\
\left(\mathrm{mg} / \mathrm{cm}^{2}\right)\end{array}$ & $\begin{array}{l}\text { Capacity of the } \\
\text { cell }\left(\mathrm{mAh} / \mathrm{cm}^{2}\right)\end{array}$ & $\begin{array}{l}\mathrm{m}_{\text {whole }} \text { (anode }+ \\
\text { cathode) }\left(\mathrm{mg} / \mathrm{cm}^{2}\right)\end{array}$ & $\begin{array}{l}\text { Cell voltage } \\
\text { (V) }\end{array}$ & $\begin{array}{l}\text { Energy of the cell } \\
\left(\mathrm{mWh} / \mathrm{cm}^{2}\right)\end{array}$ & $\begin{array}{l}\text { Specific energy of the } \\
\text { cell }(W \mathrm{~h} / \mathrm{kg})\end{array}$ \\
\hline Graphite & 95 & 360 & & 3,90 & 3,71 & 10,84 & 3,09 & 32,30 & 3,2 & 9,9 & 306 \\
\hline Si/Graphite & 85 & 1100 & & 4,36 & 3,71 & 3,97 & 3,09 & 25,42 & 3 & 9,3 & 365 \\
\hline $\mathrm{ZnFe2O4}$ & 75 & 1000 & & 4,94 & 3,71 & 4,94 & 3,09 & 26,40 & 1,7 & 5,3 & 199 \\
\hline LiFePO4 & 90 & 160 & & 3,43 & 3,09 & 21,45833333 & & & & & \\
\hline
\end{tabular}


Assumptions

The practical capacity of $3.09 \mathrm{mAh} / \mathrm{cm}^{2}$ is based on the data presented by Berg et al.

(E. J. Berg, C. Villevieille, D. Streich, S. Trabesinger and P. Novák, J Electrochem Soc, 2015, 162, A2468-A2475.)

with pre-lithiation

\begin{tabular}{|c|c|c|c|c|c|c|c|c|c|c|c|}
\hline \multicolumn{12}{|c|}{ cing ratio of 1:1 } \\
\hline $\begin{array}{l}\text { Lithium Active } \\
\text { Material }\end{array}$ & $\begin{array}{l}\text { Coulombic } \\
\text { efficiency (\%) }\end{array}$ & $\begin{array}{l}\text { Specific capacity } \\
\text { (mAh/g) }\end{array}$ & $\begin{array}{l}\text { Av. Pot. Vs. } \\
\mathrm{Li}^{\prime} \mathrm{Li}^{+}(\mathrm{V})\end{array}$ & Theoretical capacity $\left(\mathrm{mAh} / \mathrm{cm}^{2}\right)$ & $\begin{array}{l}\text { Practical capacity } \\
\left(\mathrm{mAh} / \mathrm{cm}^{2}\right)\end{array}$ & $\begin{array}{l}m_{\text {active loading }} \\
\left(\mathrm{mg} / \mathrm{cm}^{2}\right)\end{array}$ & $\begin{array}{l}\text { Capacity of the } \\
\text { cell }\left(\mathrm{mAh} / \mathrm{cm}^{2}\right)\end{array}$ & $\begin{array}{l}\mathrm{m}_{\text {whole }} \text { (anode }+ \\
\text { cathode) }\left(\mathrm{mg} / \mathrm{cm}^{2}\right)\end{array}$ & $\begin{array}{l}\text { Cell voltage } \\
\text { (V) }\end{array}$ & $\begin{array}{l}\text { Energy of the cell } \\
\left(\mathrm{mWh} / \mathrm{cm}^{2}\right)\end{array}$ & $\begin{array}{l}\text { Specific energy of the } \\
\text { cell (Wh/kg) }\end{array}$ \\
\hline Graphite & 10 & 360 & 0,2 & 3,09 & 3,09 & 8,58 & 3,09 & 27,90 & 3,2 & 9,9 & \\
\hline Si/Graphite & 10 & 1100 & 0,4 & 3,09 & 3,09 & 2,81 & 3,09 & 22,12 & 3 & 9,3 & 419 \\
\hline ZnFe2O4 & 10 & 1000 & 1,7 & 3,09 & 3,09 & 3,09 & 3,09 & 22,40 & 1,7 & 5,3 & \\
\hline LiFePO4 & 10 & 160 & 3,4 & 3,09 & 3,09 & 19,3125 & & & & & \\
\hline
\end{tabular}

\begin{tabular}{|c|c|c|c|c|c|c|c|c|c|c|c|}
\hline $\begin{array}{l}\text { Lithium Active } \\
\text { Material }\end{array}$ & $\begin{array}{l}\text { Coulombic } \\
\text { efficiency (\%) }\end{array}$ & $\begin{array}{l}\text { Specific capacity } \\
\text { (mAh/g) }\end{array}$ & $\begin{array}{l}\text { Av. Pot. Vs. } \\
\mathrm{Li}^{\mathrm{LL} \mathrm{Li}^{+}}(\mathrm{V})\end{array}$ & Theoretical capacity $\left(\mathrm{mAh} / \mathrm{cm}^{2}\right)$ & $\begin{array}{l}\text { Practical capacity } \\
\left(\mathrm{mAh} / \mathrm{cm}^{2}\right)\end{array}$ & $\begin{array}{l}m_{\text {active }} \text { loading } \\
\left(\mathrm{mg} / \mathrm{cm}^{2}\right)\end{array}$ & $\begin{array}{l}\text { Capacity of the } \\
\text { cell }\left(\mathrm{mAh} / \mathrm{cm}^{2}\right)\end{array}$ & $\begin{array}{l}m_{\text {whole }} \text { (anode + } \\
\text { cathode) }\left(\mathrm{mg} / \mathrm{cm}^{2}\right)\end{array}$ & $\begin{array}{l}\text { Cell voltage } \\
\text { (V) }\end{array}$ & $\begin{array}{l}\text { Energy of the cell } \\
\left(\mathrm{mWh} / \mathrm{cm}^{2}\right)\end{array}$ & $\begin{array}{l}\text { Specific energy of the } \\
\text { cell (Wh/kg) }\end{array}$ \\
\hline Graphite & 100 & 360 & 0,2 & 3,40 & 3,40 & 9,44 & 3,09 & 28,75 & 3,2 & 9,9 & 344 \\
\hline Si/Graphite & 100 & 1100 & 0,4 & 3,40 & 3,40 & 3,09 & 3,09 & 22,40 & 3 & 9,3 & 414 \\
\hline ZnFe2O4 & 100 & 1000 & 1,7 & 3,40 & 3,40 & 3,40 & 3,09 & 22,71 & 1,7 & 5,3 & 231 \\
\hline LiFePO4 & 100 & 160 & 3,4 & 3,09 & 3,09 & 19,3125 & & & & & \\
\hline
\end{tabular}

\begin{tabular}{|c|c|c|c|c|c|c|c|c|c|c|c|}
\hline \multicolumn{5}{|c|}{ Anode:Cathode balancing ratio of 1.2:1 } & \multirow[b]{2}{*}{$\begin{array}{l}\text { Practical capacity } \\
\left(\mathrm{mAh} / \mathrm{cm}^{2}\right)\end{array}$} & \multirow{2}{*}{$\begin{array}{l}\mathrm{m}_{\text {active }} \text { loading } \\
\left(\mathrm{mg} / \mathrm{cm}^{2}\right)\end{array}$} & \multirow{2}{*}{$\begin{array}{l}\text { Capacity of the } \\
\text { cell }\left(\mathrm{mAh} / \mathrm{cm}^{2}\right)\end{array}$} & \multirow{2}{*}{$\begin{array}{l}\mathrm{m}_{\text {whole }}(\text { anode }+ \\
\text { cathode) }\left(\mathrm{mg} / \mathrm{cm}^{2}\right)\end{array}$} & \multirow{3}{*}{$\begin{array}{l}\text { Cell voltage } \\
\text { (V) }\end{array}$} & \multirow{3}{*}{$\begin{array}{l}\text { Energy of the cell } \\
\left(\mathrm{mWh} / \mathrm{cm}^{2}\right)\end{array}$} & \multirow[b]{2}{*}{$\begin{array}{l}\text { Specific energy of the } \\
\text { cell (Wh/kg) }\end{array}$} \\
\hline $\begin{array}{l}\text { Lithium Active } \\
\text { Material }\end{array}$ & $\begin{array}{l}\text { Coulombic } \\
\text { efficiency (\%) }\end{array}$ & $\begin{array}{l}\text { Specific capacity } \\
\text { (mAh/g) }\end{array}$ & $\begin{array}{l}\text { Av. Pot. Vs. } \\
\mathrm{Li}^{\prime} \mathrm{Li}^{+}(\mathrm{V})\end{array}$ & Theoretical capacity $\left(\mathrm{mAh} / \mathrm{cm}^{2}\right)$ & & & & & & & \\
\hline Graphite & 100 & 360 & 0,2 & 3,71 & 3,71 & 10,30 & 3,09 & 29,61 & & & 334 \\
\hline Si/Graphite & 100 & 1100 & 0,4 & 3,71 & 3,71 & 3,37 & 3,09 & 22,68 & 3 & 9,3 & 409 \\
\hline ZnFe2O4 & 100 & 1000 & 1,7 & 3,71 & 3,71 & 3,71 & 3,09 & 23,02 & 1,7 & 5,3 & 228 \\
\hline LiFePO4 & 100 & 160 & 3,4 & 3,09 & 3,09 & 19,3125 & & & & & \\
\hline
\end{tabular}

